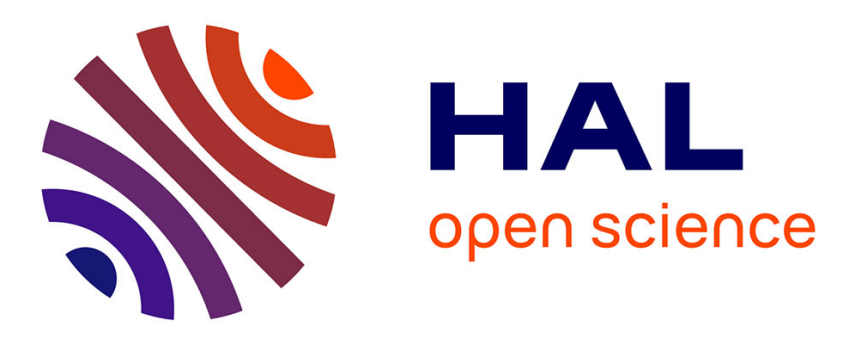

\title{
Magnetic Studies on LiZn Ferrite Films
}

\author{
J. Dash, N. Venkataramani, R. Krishnan, S. Date, S. Kulkarni, S. Prasad, S. \\ Shringi, P. Kishan, N. Kumar
}

\section{To cite this version:}

J. Dash, N. Venkataramani, R. Krishnan, S. Date, S. Kulkarni, et al.. Magnetic Studies on LiZn Ferrite Films. Journal de Physique IV Proceedings, 1997, 07 (C1), pp.C1-477-C1-478. 10.1051/jp4:19971193 . jpa-00254843

\section{HAL Id: jpa-00254843 https://hal.science/jpa-00254843}

Submitted on 1 Jan 1997

HAL is a multi-disciplinary open access archive for the deposit and dissemination of scientific research documents, whether they are published or not. The documents may come from teaching and research institutions in France or abroad, or from public or private research centers.
L'archive ouverte pluridisciplinaire HAL, est destinée au dépôt et à la diffusion de documents scientifiques de niveau recherche, publiés ou non, émanant des établissements d'enseignement et de recherche français ou étrangers, des laboratoires publics ou privés. 


\title{
Magnetic Studies on LiZn Ferrite Films
}

\author{
J. Dash, N. Venkataramani*, R. Krishnan**, S.K. Date***, S.D. Kulkarni***, S. Prasad, S.N. Shringi, \\ P. Kishan**** and N. Kumar****
}

Physics Department, I.I.T. Powai, Mumbai-400076, India

* ACRE, I.I.T. Powai, Mumbai-400076, India

** LMOV, 45 avenue des Etats-Unis, 78035 Versailles, France

*** NCL, Pune 411008, India

**** SSPL, Lucknow Road, Delhi 110054, India

\begin{abstract}
In this paper, we report the study of the magnetic properties of ( $\mathrm{Li}_{0.5-x / 2} \mathrm{Mu}_{0.1} \mathrm{Zn}_{x} \mathrm{Fe}_{2.35-x / 2} \mathrm{O}_{4}$ ) filans with $x=0,0.16,0.32,0.48$. The films were deposited on fused quartz substrates by $\mathrm{r} f$ sputtering technique under various deposition conditions. The magnetic properties of the films annealed at $750^{\circ} \mathrm{C}$ are being reported. The $M$, values of the films deposited at a rf power of $240 \mathrm{~W}$ in argon atmosphere were found to be smaller than the corresponding bulk values. The $M$, value was found to be maximum at $x=0.32$, similar to the bulk. The $H_{\mathrm{c}}$ values of the films are much higher than the bulk values and decrease as a function of $x$.
\end{abstract}

\section{Introduction}

Lithium ferrites are good material for low power microwave devices with low dielectric losses. Substitution of diamagnetic zinc increases the magnetization and make these ferrites useful for latching devices. Recent microwave integrated circuit design demands the use of ferrites in thin film form. In the literature, there are very few reports on lithium ferrite thin films[1,2]. Oliver et al.[2] have deposited $\mathrm{Li}_{0.45} \mathrm{Zn}_{0.1} \mathrm{Mn}_{0.05} \mathrm{Fe}_{2.4} \mathrm{O}_{4}$ films on $\mathrm{MgO}$ single crystal substrates using pulsed laser deposition technique (PLD). We have earlier reported the magnetic properties of $\mathrm{Li}_{0.5-x / 2} \mathrm{Mn}_{0.1} \mathrm{Zn}_{x} \mathrm{Fe}_{2.35-x / 2} \mathrm{O}_{4}$ films with $x=0.32$ [3], deposited on amorphous fused quartz substrates with various depasition conditions by $\mathrm{rf}$ sputtering. We have carried out a systematic study of lithium gine ferrite (I,i7n) films for different values of $x$. In this paper, we report the magnetic properties of these films with $x \simeq 0,0.16,0.32,0.48$.

\section{Experimental}

Lithium zinc ferrite films were deposited in a Leybold $\mathrm{Z} 400$ rf sputtering unit. Four polycrystalline LiZn ferrite targets with varying zinc concentration were used for deposition. Before sputtering, the chamber was evacuated to $2 \times 10^{-6}$ mbar. The films were deposited by varying rf power, $O_{2} / \mathrm{Ar}$ and target-substrate distance. In this paper, we report the films with varying $x$ deposited at a rf power of $240 \mathrm{~W}$. All the films were deposited onto fused quartz substrates in argon atmosphere. The total pressure in the chamber during deposition was $6 \times 10^{-3}$ mbar. The in-plane $M-H$ loop of the films were measured on a vibrating sample inagnetometer at room temperature.

\section{Results and discussion}

The as-deposited films were $\mathrm{x}$-ray amorphous. Films with spinel structure were obtained after annealing at $750^{\circ} \mathrm{C}$; for two hours with a lattice constant similar to the bulk.

The saturation magnetization $\left(M_{s}\right)$ values of the films as a function of $x$ is shown in Fig. 1. The bottom plot of Fig. 1 corresponds to the $M_{s}$ values of the film, whereas the top plot corresponds to the bulk[4] with composition $\mathrm{Li}_{0.5-x / 2} \mathrm{Zn}_{x} \mathrm{Fe}_{2.5-x / 2} \mathrm{O}_{4}$. It is clear that the $M_{s}$ values in the films are smaller than those expected for the bulk. 
Iite reduction of $M_{s}$ values in ferrite thin filus as compared to bulk has been observed in various types of mugnetir: thin films $[3,5-7]$. This could be because of many reasons, some of which are the presence of superparamagtetic particles and/ot uscrystallized portions and voids in the filıns. Oliver et al.[2] have observed aroursd 73-100\% of bulk $M_{s}$ values in their films deposited on single crystal substrates. Hence, it is likely that amorphous substrates used by us caused a grain structure which was responsible for lowering of $M_{s}$. One also notes from Fig. 1 that. $M_{s}$ value reaches a maximum at $x=0.32$ and thereafter decreases with increase in zinc concentration, similar to the phenomenon observed in the bulk[4]. This indicates that the films most likely maintain the composition of the target. This is also supported by the fact that our earlier studies of the energy disperive analysis of $x$-ray (ED)AX) for $x=0.32$ samples[3] indicated a composition similar to the target.

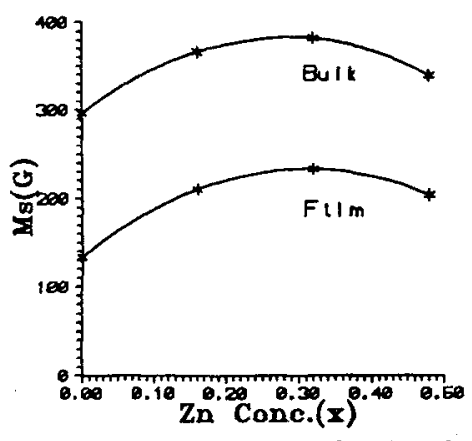

Fig. 1: $M$, values as a function of zinc concentration

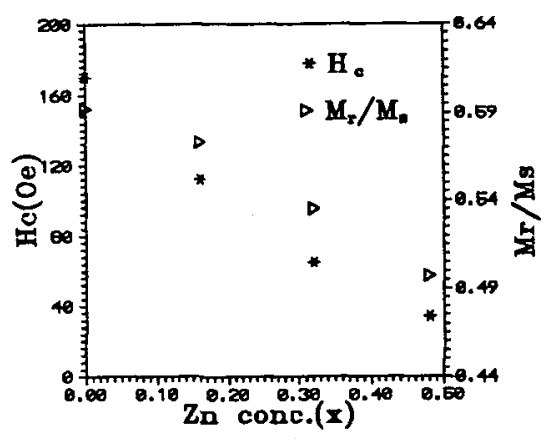

Fig. 2: $H_{c}$ and $M_{r} / M$, values as a function of ziuc concentration

The remanence ratio $\left(M_{r} / M_{s}\right)$ and coercivity $\left(H_{c}\right)$ of the films are shown in Fig. 2. As seen in the figure, the $M_{r} / M_{s}$ values decrease as $x$ increases. The $H_{c}$ values are also found to decrease almost linearly as a function of $x$. A similar decrease of $H_{c}$ with $x$ was also observed in case of bulk $\mathrm{LiZn}$ ferrites[4]. However, in bulk, the $H_{c}$ values are much smaller and were 3.75 Oe for $x=0$ and 2 Oe for $x=0.48$. Oliver et al. [2] have also reported a higher value of $H_{c}$ for their samples. Their observed $H_{c}$ values varied between $30-55$ Oe, depending upon the oxygen partial pressure. It, therefore, appears that larger values of $H_{c}$ are typical of thin films. The reason for this is not clear but may be related to microstructure or growth mechanism of the films. A study of microstructure on the films are being carried out and will be reported later.

In conclusion, we have deposited ( $\mathrm{Li}_{0.5-x / 2} \mathrm{Mn}_{0.1} \mathrm{Zn}_{x} \mathrm{Fe}_{2.35-x / 2} \mathrm{O}_{4}$ ) films with $x=0,0.16,0.32,0.48$ using rf sputtering. The $M_{s}$ values are found to be smaller than the bulk while the $\mathrm{H}_{c}$ values are much larger. The $M_{s}$ values reach a maximum at $x=0.32$ as seen in bulk.

\section{References}

[1] Zaquine I., Benazizi H. and Mage J. C., J. Appl. Phys. 64 (1988) 5822-5824.

[2] Oliver S. A., Vittoria C., Balestrino G., Martelluci S., Petrocelli C., Tebano A.and Paroli P., IEEE Trans. $M A G-30$ (1994) 4933-4935.

[3] Dash Jyotirmayee, Krishnan R., Venkataramani N., Shiva Prasad, Shringi S., Pran Kisharr and Nitendar Kumar, J. Magn. Magn. Mat. 152 (1996) L1-L4.

[4] Murthy V. R. K. and Viswanathan B., Proceedings ICF-5, India 1989, pp. 447-451.

[5] Suzuki Y., Dover R. B. Van, Gyorgy E.M., Philips Julia M., Korenivski V., Werder D. J., Chen C.II., Cavn R. J., Krajewski J.J., Peck W.F.Jr and Do K. B., Appl. Phys. Lett. 68 (1996) 714-716.

[6] Acharya Ramamurthy B., , Shiva Prasad, Venkataramani N., Shringi S. N. and Krishran R.J. Appl. Phys. 79 (1996) 478-484.

[7] Sui X. and Kryder M. H., Appl. Phys. Lett. 63 (1993) 1582. 